\title{
DUMA W PROCESIE EDUKACJI. INTERAKCYJNA ANALIZA PRZYCZYN I KONSEKWENCJI POJAWIANIA SIĘ DUMY U NAUCZYCIELI I UCZNIÓW
}

\begin{abstract}
AвSTRACT. Pawłowska Beata, Duma w procesie edukacji. Interakcyjna analiza przyczyn i konsekwencji pojawiania się dumy u nauczycieli i uczniów [Pride in the Education Process. Interactional Analysis of Causes and Consequences of Pride Emergence among Students and Teachers]. Studia Edukacyjne nr 53, 2019, Poznań 2019, pp. 255-274. Adam Mickiewicz University Press. ISSN 1233-6688. DOI: 10.14746/ se.2019.53.14
\end{abstract}

The aim of the article is to show how pride arises in teachers' work and students' learning process. Therefore, school and the education process will be shown through the prism of emergence of one social emotion: pride. In contrast, in some cases, pride is juxtaposed with another social emotion - shame. The emphasis will be placed on pride as the emotion which refers to the diagnosis of social bonds and leads to experiencing other emotions such as joy, happiness, satisfaction, etc. It is assumed that frequent experiencing of pride leads to increased self-esteem. I will refer to the concept of Theodore D. Kemper, i.e. a theoretical frame which assumes that emotions arise on the basis of social relations and pride is a result of satisfaction emerging due to the growth of our status. I will moreover invoke the theory of Thomas Scheff, who indicates e.g. that pride as an emotion customizes our behaviors without supervision and control. From a sociological perspective and under an interpretative approach, pride will be treated as a social emotion. The article sums up reflections based on qualitative research conducted by the author in the years 2006-2014.

Key words: qualitative research, pride, shame, Theodore D. Kemper, Thomas Scheff

\section{Wstęp}

Współczesny nauczyciel działając w warunkach ciągłej zmiany, aby efektywnie funkcjonować w szkole, a w szczególności w klasie szkolnej, musiał wypracować pewne mechanizmy pozwalające odczuwać zadowolenie i satysfakcję z pracy. Obecnie w polskiej szkole brakuje w zasadzie efektywne- 
go systemu motywowania nauczyciela, dlatego tak ważną rolę w procesie motywowania odgrywają odczuwane przez jednostkę emocje, w tym emocja dumy.

Duma jako jedna $z$ istotniejszych emocji społecznych ${ }^{1}$ wpływa w znaczący sposób nie tylko na zachowanie i pracę nauczycieli, ale także uczniów, stanowiąc ważny element zarówno procesu edukacji, jak również socjalizacji.

Celem niniejszego artykułu jest wskazanie na emocję dumy jako tę, która odnosi się do diagnozy stanu więzi społecznej oraz często odczuwana prowadzi do wzrostu samooceny. Pokazany zostanie wpływ odczuwania emocji dumy na wzrost zadowolenia z pracy nauczyciela.

Duma będzie traktowana jako emocja społeczna, w myśl perspektywy socjologicznej i podejścia interpretatywnego.

Miejscem pracy nauczyciela jest szkoła, rozumiana najczęściej jako placówka oświatowa o charakterze edukacyjnym. Jednak szkoła to także, a może przede wszystkim, uczniowie, którzy spędzają w jej murach od 5 do nawet 9 godzin dziennie. Dzieci i młodzież nie tylko zdobywają w niej szeroko rozumianą wiedzę, ale także odczuwają wiele emocji - od radości, zadowolenia, podziwu i dumy, poprzez rozczarowanie, strach, gniew, wściekłość, przerażenie, po zażenowanie, wstyd, wstręt, żal, nudę i miłość (zob. Plutchnik, 1980). Istotny wpływ na kształtowanie i pojawianie się określonych emocji mają rówieśnicy, ale także nauczyciele. To ich zachowanie i działania wpływają na pojawienie się u ucznia emocji społecznych dumy lub wstydu. Dlatego interesująca będzie odpowiedź na pytanie o emocje pojawiające się u uczniów w toku ich edukacji.

Podstawę teoretyczną stanowi przede wszystkim koncepcja Theodore D. Kempera ${ }^{2}$, zakładająca, że emocje powstają na bazie relacji społecznych, a duma jest efektem powstania satysfakcji na skutek wzrostu naszego statusu oraz teoria Thomasa Scheffa ${ }^{3}$, wskazująca między innymi na dumę jako emocję zapewniającą regulację naszych zachowań bez konieczności nadzoru i kontroli.

${ }^{1}$ Zob. T. Scheff, Shame and Conformity: The Deference Emotion System, American Sociological Review, 1988, 53, s. 395-406; Microsociology. Discurse, emotion, and social structure, Chicago 1990; Shame and the social bond, and human reality, New York 2000.

2 T. Kemper, A Social Interactional Theory of Emotions, New York 1978; How many emotions are there? Wedding the social and autonomic components, American Journal of Sociology, 1987, 93, s. 263-289; Predicting Emotions from Social Relations, Social Psychology Quarterly, 1991, 54, s. 330342; Modele spoteczne w wyjaśnianiu emocji, [w:] Psychologia emocji, red. M. Lewis, J.M. HavilandJones, Gdańsk 2005; Power, status, and emotions, [w:] Emotions a social science reader, red. M. Greco, P. Stenner, London - New York 2008.

${ }^{3}$ T. Scheff, Shame and Conformity, s. 395-406; Microsociology. Discurse, emotion; Shame and the social bond; Shame and self in society, Symbolic Interaction, 2003, 26, s. 239-262. 


\section{Duma w koncepcji Thomasa Scheffa}

Jak piszą Turner i Stets ${ }^{4}$, Thomas Scheff "łączy idee tradycji interakcjonizmu symbolicznego i psychoanalizy w ogólną teorię emocji". Centralne miejsce zajmuje tu pojęcie dumy oraz wstydu powstające z zakłopotania i zażenowania. Scheff korzystał między innymi z prac Cooleya, Goffmana, Freuda, Lewis i Adlera, gdzie na idei wstydu bazuje dążenie do prestiżu i poczucie niższości, Horney, dla której duma i wstyd były kluczem do zrozumienia zachowań normalnych i neurotycznych, oraz Keltner i Buswell, wskazujących na to, że wstyd uwidacznia się w innej mimice. Jest to zażenowanie ukrywane (przykrywane) śmiechem ${ }^{5}$. Wstyd w koncepcji Scheffa stanowi pierwszą i najważniejszą emocję społeczną powstającą w momencie zagrożenia więzi społecznej ${ }^{6}$. Definicja ta stara się integrować jaźń (reakcje emocjonalne) i społeczeństwo (więzi społeczne) 7 . Emocje są elementem jaźni odzwierciedlonej i podstawą kontroli społecznej. Duma pojawia się wówczas, gdy przestrzegamy norm społecznych. Kiedy tego nie robimy - pojawia się wstyd. Ponieważ dążymy do odczuwania emocji pozytywnych, jak na przykład duma, to skutkiem jest konformizm społeczny i wysoki stopień stabilności społecznej. Zatem, duma i wstyd zapewniają społeczną regulację zachowań, bez konieczności zewnętrznego nadzoru ${ }^{8}$. Pojawienie się wstydu i dumy zależy od jakości relacji społecznych. Wstyd jest rezultatem negatywnych sankcji społecznych, a duma - wynikiem wzajemnej akceptacji i szacunku ${ }^{9}$. Duma to emocja wtórna nadbudowana na emocjach pozytywnych i wchodząca w skład "rodziny emocji zadowolenia"10.

Do więzi społecznej odnoszą się dwie emocje: duma i wstyd. To one informują o stanie więzi społecznej ${ }^{11}$. Duma i wstyd są podstawowymi społecznymi emocjami. Duma jest pozytywną emocją, która sprawia, że jednostki dostrajają się do swoich wzajemnych reakcji (przyjmując rolę innego) ${ }^{12}$. Jest sygnałem nienaruszonej więzi, a wstyd stanowi sygnał więzi zagrożonej lub naruszonej w jakiś sposób. Jeśli idea więzi społecznej jest obecnie stłumiona, podobnie będą stłumione te dwa rodzaje emocji. Często używa się pewnego

\footnotetext{
${ }^{4}$ J. Turner, J. Stets, Socjologia emocji, Warszawa 2009, s. 174.

${ }_{5}$ Zob. T. Scheff, Microsociology. Discurse, emotion; Shame and the social bond; Shame and self in society, s. 239-262.

${ }^{6}$ T. Scheff, Shame and the social bond, s. 84.

7 Zob. T. Scheff, Microsociology. Discurse, emotion.

8 Zob. tamże.

9 J. Stets, Identity Theory and Emotions, [w:] Handbook of the Sociology of Emotions, red. J.E. Stets, J.H. Turner, New York 2006.

${ }^{10}$ D. Goleman, Inteligencja emocjonalna, Poznań 1997.

${ }_{11}$ Por. T. Scheff, Microsociology. Discurse, emotion, s. 12.

12 Zob. J. Turner, J. Stets, Socjologia emocji, s. 174.
} 
kodu językowego by wyrazić lub ukryć określone emocje: „czułem się niepewnie", "czułem się dziwnie", "czułem się niekomfortowo" i tym podobnie. We współczesnych społeczeństwach zaprzeczenie wstydu jest zinstytucjonalizowane w języku. Wstyd i duma są ciągłymi sygnałami stanu więzi, ciągłym odczytywaniem temperatury relacji międzyludzkich. Kiedy jednostki doświadczają braku poważania i szacunku ze strony innych, same siebie oceniają negatywnie i doświadczają w ten sposób wstydu. Jeżeli wstyd jest uświadamiany, może prowadzić do zdrowej rekonstrukcji więzi społecznej, jeżeli natomiast nie jest uświadamiany na skutek tłumienia, czy wypierania, to uruchamia cykl wstydu i złości, który z kolei może doprowadzić do silnego zakłócenia więzi społecznych ${ }^{13}$.

Na koniec warto wspomnieć, za Scheffem, że znaczenia wszystkich ludzkich ekspresji mają charakter kontekstualny. Znaczenie ludzkiej ekspresji nie jest raz na zawsze ustalone; ekspresja wskazuje tylko relacje pomiędzy sobą i kontekstem w którym występuje ${ }^{14}$.

\section{Duma w wymiarach władzy i statusu w teorii Theodore D. Kempera ${ }^{15}$}

Theodore Kemper jest jednym z wczesnych pionierów socjologii emocji, pierwotnie rozwijającym "społeczno-interakcyjną teorię emocji” oraz teorię bazującą na procesach biologicznych ${ }^{16}$. Później rozpoczął współpracę z Randallem Collinsem, aby stworzyć nową teorię opierającą się na władzy i statusie. Kemper wychodzi z założenia, że emocje powstają na bazie relacji społecznych. Jednakże, w opisie tych relacji ogranicza się do dwóch wymiarów: „władzy” i „statusu”, uznając je za optymalne i takie, za pomocą których można opisać oraz scharakteryzować wszelkie związki interpersonalne. Według niego, zmiany względnej władzy i statusu (prestiżu) jednostek mają wpływ na wzbudzanie negatywnych i pozytywnych emocji ${ }^{17}$.

Władzę rozumie, za Weberem, jako stan w relacjach międzyludzkich, w którym jeden aktor społeczny zmusza drugiego do zrobienia czegoś, na co ten drugi nie ma ochoty. Środki, jakimi dysponuje osoba posiadająca władzę to groźby, rzeczywiste użycie siły, pozbawienie pewnych dóbr materialnych,

13 Tamże, s. 175; T. Scheff, Microsociology. Discurse, emotion, s. 15.

${ }^{14}$ T. Scheff, Microsociology. Discurse, emotion, s. 37-38 i 51.

${ }^{15}$ Więcej na temat teorii Theodore'a Kempera czytelnik znajdzie w artykule Beaty Pawłowskiej, Emocje społeczne w teorii Theodore'a Kempera, opublikowanym w książce: Krzysztof Konecki, Beata Pawłowska (red.), Emocje w życiu codziennym. Analiza kulturowych, społecznych i organizacyjnych uwarunkowań ujawniania i kierowania emocjami, Łódź 2014.

${ }^{16}$ J. Turner, J. Stets, Socjologia emocji, s. 240.

17 Zob. T. Kemper, Power, status, and emotions, [w:] Emotions. 
symbolicznych lub przeżyć, kłamstwo, oszustwo i manipulacja. O władzy można mówić jako o procesie powodującym takie zaprojektowanie swoich aktualnych i przyszłych działań, w konsekwencji których powstaje chęć zwycięstwa.

Status natomiast rozumiany jest jako pewien stan $\mathrm{w}$ relacjach społecznych, który dotyczy dobrowolnego zastosowania się do interesów i wymogów innej osoby. Status jednego aktora nadawany jest przez drugiego poprzez akty uznania wartości tego pierwszego. Ma on, podobnie jak władza, charakter procesu. Przejawami uznania statusu jest okazywanie troski, sympatii, wsparcia, nagradzania, szacunku, przyjaźni i w końcu miłości.

Wszelkie zmiany $\mathrm{w}$ relacjach społecznych mogą być rozumiane jako wzajemne zmiany władzy i statusu aktorów wobec siebie. Prowadzą one do zmian w ekspresji każdego z nich oraz w strukturze relacji poprzez oznaczenie działania na indywidualnym, jednostkowym poziomie władzy i statusu. Zatem, Kemper postuluje, że jeżeli chcemy zrozumieć występowanie wielu ludzkich emocji, musimy zbadać strukturę oraz proces władzy i statusu w relacjach między aktorami społecznymi. Podejście to obejmuje zarówno emocje negatywne, jak: złość, depresja, poczucie winy, wstyd, niepokój, ale też emocje pozytywne, jak: szczęście, troska, duma, prawość i miłość ${ }^{18}$.

Kemper prowadząc analizy socjologicznych modeli i podejść do badania emocji, wskazuje na kilka głównych teoretycznych ujęć emocji, które mogą inspirować nas do dalszych badań. $Z$ punku widzenia problematyki niniejszego artykułu istotne jest stwierdzenie, że emocje oparte są na relacjach społecznych ${ }^{19}$ i zależne od statusu oraz władzy. Teoria ta sugeruje, że znaczna liczba ludzkich emocji może być rozumiana jako reakcje na posiadaną władzę i/lub status oraz ich implikacje w różnych sytuacjach. W tym kontekście Kemper analizuje takie emocje, jak poczucie bezpieczeństwa, lęk, poczucie winy, szczęście, wstyd, zakłopotanie, depresja, optymizm i pesymizm, a nawet miłość. Sugeruje, że do powstania poczucia winy, wstydu, lęku i depresji jako charakterystycznych nastrojów oraz skłonności dochodzi w procesie socjalizacji i zależy to od rodzaju (typu) stosowanej kary w wymiarze władzy i statusu (karanie fizyczne - ukierunkowane na władzę lub karanie psychiczne - ukierunkowane na status, np. zawstydzenie), od proporcjonalności kary (czy kara jest adekwatna do pełnionego czynu), od samego aktu karania oraz czy osoba karząca jest głównym źródłem emocji (uczucia, np. miłości) lub statusu $^{20}$. Kemper tym samym udowadnia, jak bardzo negatywne emocje są wynikiem uspołecznienia. Czytamy:

${ }^{18}$ Zob. tamże, s. 128.

19 T. Kemper, A Social Interactional Theory.

${ }^{20}$ Zob. tamże; K. Strongman, The psychology of emotions. Fifth edition. From everyday life to theory, Chichester 2003, s. 267. 
Prześledzenie kilku wersji owego modelu przynosi w efekcie zestaw ośmiu hipotez wyjściowych, dotyczących tego, jak każda z negatywnych emocji podlega socjalizacji w postaci charakterystycznej cechy osobowości oraz jaki jest typowy sposób radzenia sobie, kiedy wzbudzeniu ulega negatywna emocja. Na przykład kara ukierunkowana na status proporcjonalnie do powagi czynu poddaje socjalizacji wstyd jako emocję charakterystyczną. Jeśli karzący stanowi również główne źródło uczucia (rodzic), to przystosowanie będzie ukierunkowane na kompensację wobec tych osób, w stosunku do których człowiek zachował się w sposób zasługujący na wstyd. Jeżeli karzący nie kontroluje swoich uczuć, to sposobem radzenia sobie będzie przypuszczalnie charakterystyczny superkrytyczny perfekcjonizm ${ }^{21}$.

Cytat ten pokazuje, jak socjalizacja wpływa na okazywanie emocji oraz jak prowadzi to do wykształcenia się określonych cech osobowości.

Na podstawie wyników uzyskanych w rezultacie prowadzonych przez siebie badań i eksperymentów laboratoryjnych dotyczących emocji, poziomu władzy i statusu w relacjach społecznych, Kemper ${ }^{22}$ stwierdził, że obszerna klasa ludzkich emocji stanowi rzeczywisty, przewidywany, wyobrażony lub zapamiętany rezultat relacji społecznych. Rozpatrywać je można na czterech wymiarach ${ }^{23}$. Zważywszy na problematykę artykułu, najbardziej interesujący jest wymiar trzeci, nazwany „status Ja”. Wzrost statusu, na jaki naszym zdaniem zasługujemy, prowadzi do satysfakcji i w konsekwencji powstania poczucia szczęścia, dumy (jeżeli sami byliśmy czynnikiem sprawczym), wdzięczności (jeżeli czynnikiem sprawczym był ktoś inny). Wzrost statusu przekraczający nasze oczekiwania powoduje radość lub wstyd. Spadek statusu wzbudza gniew (jeżeli sprawcą był ktoś inny) lub wstyd (jeżeli sprawcą byliśmy my sami). Jeżeli sytuacja taka uznana zostanie za nieodwracalną, może to prowadzić do powstania depresji.

Powstające emocje oparte są na wcześniejszym doświadczeniu dotyczącym kontaktów międzyludzkich i postrzeganiu ich w kategoriach władzy oraz statusu. Takie kontakty mogą budzić optymizm lub pesymizm oraz określać poziom zaufania lub brak zaufania.

Należy pamiętać, że postrzeganie władzy i statusu, a w konsekwencji powstanie określonej relacji i emocji będzie zależeć od kilku czynników, że na przykład:

1) specyficzna kultura określa indywidualny poziom władzy i statusu oraz jego postrzeganie ${ }^{24}$;

${ }^{21}$ T. Kemper, Modele społeczne w wyjaśnianiu emocji, [w:] Psychologia, s. 75.

22 T. Kemper, A Social Interactional Theory.

${ }^{23}$ Por. T. Kemper, Modele spoteczne w wyjaśnianiu emocji, [w:] Psychologia.

${ }^{24}$ Warto wskazać w tym miejscu na badania G. Hofstede nad postrzeganiem wśród pracowników dystansu władzy definiowanego przez niego jako zakres oczekiwań $i$ akceptacji dla nierównego rozkładu władzy, wyrażany przez mniej wpływowych (podwładnych) członków instytucji lub organizacji (G. Hofstede, Kultury i organizacje, Warszawa 2000, s. 67; por. także Ch. Robert 
2) pozycja społeczna różnie jest postrzegana w różnym czasie;

3) specyficzne organizacje społeczne mogą wyznaczać różne wzory zachowań emocjonalnych poprzez przypisywanie im różnych statusów.

Władza i status łącznie tworzą zrąb relacji społecznych, będący u podnóża wszystkich interakcji społecznych. Dostarczają jednostce mniejszą lub większość ilość zasobów emocjonalnych o względnie trwałym charakterze.

Duma w koncepcji Kempera jest wynikiem powstania satysfakcji na skutek wzrostu naszego statusu i / lub władzy na jaki(ą) naszym zdaniem zasłużyliśmy na skutek działań podjętych przez nas samych lub działań podjętych przez kogoś innego 25 .

\section{Metodologia badań}

Przyjęta metodologia badań (jakościowych) odzwierciedla schematy myślowe aktorów społecznych i pozwala spojrzeć na codzienną naturę interakcji ${ }^{26}$.

Zawarte $\mathrm{w}$ artykule przemyślenia są wynikiem: 1) wielokrotnych obserwacji uczestniczących i quasi-uczestniczących prowadzonych przez autorkę w latach 2006-2014 na terenie szkół podstawowych i gimnazjów z aglomeracji łódzkiej; 2) analiz wywiadów swobodnych mało ustrukturalizowanych oraz ustrukturalizowanych prowadzonych przez autorkę z obecnymi nauczycielami, emerytowanymi nauczycielami, rodzicami, dyrektorami szkół i pozostałymi pracownikami szkól; 3) analiz dokumentów zastanych i stron internetowych badanych szkół; 4) analiz wywiadów dotyczących dotychczasowej edukacji przeprowadzonych z byłymi uczniami, a obecnymi studentami studiów stacjonarnych kierunku analityka społeczna w latach 2014-2016.

Należy podkreślić, że obserwacje zajęły łącznie kilkanaście miesięcy. W miarę możliwości autorka pragnęła uczestniczyć we wszystkich ważniejszych wydarzeniach mających miejsce $\mathrm{w}$ życiu szkoły. Wymienić należy udział w: zajęciach lekcyjnych, pozalekcyjnych zajęciach oferowanych w szkole w ramach dwóch dodatkowych godzin pracy nauczyciela (koła zainteresowań, zajęcia wyrównawcze), przerw pomiędzy lekcjami, zajęć świetlicowych, akademiach szkolnych, zebrań i spotkań nauczycieli z rodzicami, zebrań rodziców w ramach zebrań Rady Szkoły i/lub Rady Rodziców oraz

i in., Empowerment and Continuous Improvement in the United States, Mexico, Poland, and India: Predicting Fit on the Basis of the Dimensions of Power Distance and Individualism, Journal of Applied Psychology, 2000, 85, 5, s. 644).

${ }^{25}$ B. Pawłowska, Emocje społeczne w pracy nauczyciela i przedstawiciela handlowego, Łódź 2013, s. 198.

${ }^{26}$ Zob. E. Goffman, Instytucje totalne. O pacjentach szpitali psychiatrycznych i mieszkańcach innych instytucji totalnych, Sopot 2011, s. 8. 
zebrań samych nauczycieli (rad pedagogicznych). Bardzo ważnym elementem wszystkich obserwacji były nieformalne rozmowy prowadzone $\mathrm{z}$ rodzicami (m.in. przed lub/i po zebraniach z nauczycielami, w czasie kiedy rodzice oczekiwali na swoje dzieci po skończonych lekcjach), nauczycielami, woźnymi i personelem administracyjnym (m.in. podczas przerw), uczniami (m.in. podczas przerw i godzin wychowawczych) i dyrektorami placówek (m.in. przed lub/i po akademiach, zebraniach). Pozwoliły one na konstruowanie pytań do wywiadu swobodnego, ale także na weryfikację danych uzyskiwanych w wywiadach. W sumie autorka przeprowadziła 93 wywiady z obecnymi nauczycielami, w tym dyrektorami szkół, 18 wywiadów z nauczycielami emerytowanymi, 19 wywiadów z rodzicami uczniów, 14 wywiadów z szeroko rozumianym personelem administracyjnym. Średni czas trwania jednego wywiadu wynosił 39 minut. W wywiadach starałam się zwrócić uwagę na istotne elementy występujące $\mathrm{w}$ pracy nauczyciela, ze szczególnym wskazaniem na momenty trudne (negatywne) i przyjemne (pozytywne). Ekspresja emocjonalna obserwowana była podczas zajęć lekcyjnych. Następnie, bezpośrednio po lekcji, rozmawiałam z nauczycielem o powstałych w czasie zajęć lekcyjnych emocjach, przez co miał(a) on(a) możliwość odniesienia się do zaobserwowanych przez badacza faktów.

Zdaję sobie sprawę z ograniczeń wynikających z zakresu moich badań, $\mathrm{w}$ tym $\mathrm{z}$ zebranego materiału badawczego. Zastosowane $\mathrm{w}$ badaniu metody jakościowe w zakresie wybranych technik badawczych stworzyły możliwość nawiązania dłuższego i bliższego kontaktu z badanymi. Technika wywiadu pogłębionego dała szansę stworzenia okoliczności zbliżonych do swobodnej rozmowy z badanym na interesujące mnie tematy ${ }^{27}$. Ponadto, obserwacja jako technika popularna wśród socjologów organizacji ${ }^{28}$ pozwoliła na weryfikację informacji udzielanych przez badanych i przedarcia się przez deklaratywną warstwę danych uzyskanych drogą wywiadu ${ }^{29}$. Obserwacja umożliwiła mi niejako "na żywo" przekonanie się o emocjach towarzyszących występowaniu sytuacji stresowych, a także sformułowanie dalszych pytań wobec badanych. Dłuższy kontakt zarówno z nauczycielami, jak również z uczniami sprawił, że po jakimś czasie moja osoba badacza „wtapiała się" w grupę klasową i przestawała być obiektem zainteresowania ze strony uczniów, co miało istotne znaczenie dla jakości uzyskanych w ten sposób danych.

27 Por. J. Lutyński, za: I. Przybyłowska, Wywiad swobodny ze standaryzowana listą poszukiwanych informacji i możliwości jego zastosowania w badaniach socjologicznych, Przegląd Socjologiczny, 1978, XXX; K. Konecki, Studia z metodologii badań jakościowych. Teoria ugruntowana, Warszawa 2000.

${ }_{28}$ K. Doktór, Przedsiębiorstwo przemystowe. Studium socjologiczne Zakładów Przemystu Metalowego „Cegielski”, Warszawa 1964; K. Konecki, W japońskiej fabryce, Łódź 1992 i in.

29 Por. B. Pawłowska, Emocje społeczne w pracy nauczyciela. 
Na uwagę zasługuje również fakt, że podstawę (inspirację) badań stanowiły także nieformalne rozmowy z nauczycielami i rodzicami, które poprzedzały oraz następowały po obserwacjach i wywiadach.

Badania miały charakter badań terenowych i zostały oparte na dwóch podejściach metodologicznych, to jest etnografii (przede wszystkim etnografii analitycznej) oraz teorii ugruntowanej. Etnografia analityczna pozwoliła na gromadzenie danych empirycznych w naturalnym, codziennym i podstawowym kontekście, w którym zachodziły analizowane zjawiska ${ }^{30}$. W celu pogłębienia wglądu w badaną rzeczywistość ograniczono liczbę przypadków do trzech szkół, a wywiady przeprowadzono także z nauczycielami obecnymi i emerytowanymi pracującymi także $w$ innych placówkach oświatowych ${ }^{31}$. Metodologia teorii ugruntowanej porządkowała proces badawczy i wyznaczała strategię pracy $\mathrm{z}$ danymi. Została ona dobrze opisana w literaturze przedmiotu, dlatego jej dokładny opis zostanie pominięty w niniejszym opracowaniu ${ }^{32}$.

\section{Duma jako motywator w pracy nauczyciela}

Duma jest jedną z emocji pochodnych dla psychologów i podstawową emocją społeczną dla socjologów. Emocja dumy odnosi się do diagnozy stanu więzi społecznej. Informuje o nienaruszonym jej charakterze. Jak już zostało zaznaczone powyżej, duma jest emocją pozytywną, która sprawia, że jednostki dostrajają się do swoich wzajemnych reakcji.

W wywiadach swobodnych rozmówcy chętnie dzielili się sytuacjami, w których pojawiała się emocja dumy. Bardzo często w narracji uczucie to nazywano wprost. Czasami rozmówcy mówili o szczęściu, zadowoleniu, radości, satysfakcji. Jest to grupa emocji pokrewnych do dumy. Można powiedzieć, że każdemu z tych uczuć towarzyszy duma. Zawsze kiedy pojawiała się narracja związana z emocją dumy, pojawiała się informacja o wzroście

${ }^{30}$ Zob. M. Hammersley, P. Atkinson, Ethnography: Principles in Practice, New York 2007; M.J. Deegan, The Chicago School of Ethnography, [w:] Handbook of Ethnography, red. P. Atkinson, A. Coffey, S. Delamont, J. Lofland, L. Lofland, Thousand Oaks 2001.

${ }^{31}$ Zob. M. Burawoy, The Extended Case Method, Sociological Theory, 1998, 16(1).

32 Zob. B.G. Glaser, A.L. Strauss, The Discovery of Grounded Theory: Strategies for Qualitative Research, Chicago 1967; Odkrywanie teorii ugruntowanej. Strategie badania jakościowego, Kraków 2009; A.L. Strauss, J. Corbin, Grounded Theory in Practice, Thousand Oaks 1997; K. Charmaz, Constructing Grounded Theory: A Practical Guide Through Qualitative Analysis, London - Thousand Oaks - New Delhi 2006; Teoria ugruntowana. Praktyczny przewodnik po analizie jakościowej, Warszawa 2009; K. Konecki, Studia z metodologii badań jakościowych; M. Gorzko, Procedury i emergencja. O metodologii klasycznych odmian teorii ugruntowanej, Szczecin 2008. 
zadowolenia z pracy. Należy zatem uznać, że uczucie dumy jest emocją bezpośrednio wpływającą na wzrost motywacji do działania. Prowadzi ono do pojawiania się satysfakcji z pracy, a to - do wzrostu motywacji i wzrostu dążeń jednostki do osiągnięć.

W moich badaniach emocja dumy pojawiła się w trzech głównych kontekstach. Pierwszy związany jest z dumą z przynależności do organizacji i/lub grupy zawodowej. Rozmówcy wprost wskazywali na dumę bądź satysfakcję z pracy właśnie w takiej a nie innej szkole lub zawodzie nauczyciela.

(...) dosyć, dosyć taki no w miare, jeśli chodzi o te gradacje, prestiż tego zawodu, no w miarę, nie jest jakiś tam, ale w miarę, w miarę satysfakcjonujący (kobieta, lat 27, obecny nauczyciel).

miło jest pracować w najlepszej szkole w mieście (kobieta, lat 54, obecny nauczyciel).

Drugi wymiar odnosi się do osiągnięć i wymiernych sukcesów w pracy (np. otrzymywanie nagród i odznak).

Muszę Pani jeszcze nieskromnie (lekki uśmiech, zaczerwienienie) powiedzieć, że za swa prace pedagogiczna i społeczna odznaczona zostałam Srebrnym i Złotym Krzyżem Zastugi. Otrzymałam kilka odznak regionalnych, których nazw w tej chwili nie pamiętam oraz prestiżowa Nagrodę Ministra Oświaty i Wychowania (kobieta, lat 84 , emerytowany nauczyciel).

Dumna jestem ze swoich osiagnięć. Prowadziłam wiele lekcji pokazowych. $W$ tamtym czasie byłam najlepsza w Łodzi. Należałam do elitarnego Klubu Nauczycieli Twórczych. Dostawałam wiele nagród Kuratora Oświaty, a nawet nagrodę pierwszego stopnia Ministra Oświaty i Wychowania. Każda nagroda pobudzała. Jeszcze bardziej chciato mi się zarywać noce i przygotowywać pomoce. Każde zajęcia były inne. Nigdy nie popadtam w rutynę. To też uważam za sukces (kobieta, 64 lata, emerytowany nauczyciel).

Jedna nauczycielka opowiadała o sytuacji, w której po zakończeniu lekcji pokazowej, jaką prowadziła dla grupy dyrektorów, wizytatorów i nauczycieli innych szkól, została publicznie pochwalona. Pochwała ta wypowiedziana została przez dyrektora innej placówki oświatowej. Wydarzenie to spowodowało u niej dużą satysfakcję oraz dumę. Z zaprezentowanego poniżej fragmentu wypowiedzi wyraźnie widać, że wzrosła samoocena i motywacja do pracy. 
(...) jeden z dyrektorów powiedziat: o, chętnie chciałbym mieć taka sama matematyczkę u siebie. Wtenczas poczułam yyy, poczułam, że mogę być akceptowana naprawdę. Bo to, że twój szef tak na ciebie patrzy a nie inaczej, to inna rzecz. On cie widzi na co dzien, zna twoje błędy, zna twoje zalety. To inaczej. A przyjeżdża ktoś $z$ zewnątrz $i$ widzi cię $w$ akcji, widzi cię w czasie pracy, tylko w pracy $i$ ze potrafi się człowiek tak pokazać, że no yyy chcieliby mieć taka nauczycielkę. To było dla mnie yyy miłe byto. (...) wtenczas uwierzyłam, że to co ja robię, ten styl prowadzenia lekcji to jest takie yyy dobre. Aż chce ci się chcieć. Wtenczas czutam się dowartościowana (kobieta, lat 46, obecny nauczyciel).

Należy zauważyć, że całe zdarzenie miało charakter publiczny, co z pewnością także przyczyniło się do pojawienia się emocji dumy i wzrostu samooceny. Pozwoliło na podtrzymanie pozytywnego wizerunku samego siebie. Zgodnie z teorią porównań społecznych Leona Festingera ${ }^{33}$, ludzie mają potrzebę oceniania siebie, w celu uzyskania trafnego obrazu własnego ja. Wykorzystując kryteria obiektywne (pochwała), nauczycielka oceniła swoje zdolności i mocne strony. Dokonała porównania z innymi matematyczkami. Mogła uznać, że skoro chwalący dyrektor chciałby mieć taką nauczycielkę jak ona u siebie, to pozostałe pracujące w innej placówce matematyczki muszą być od niej gorsze. Nastąpił także wzrost statusu w myśl omówionej koncepcji Kempera.

Trzeci i najciekawszy, moim zdaniem, wymiar związany jest z osiągnięciami innych osób, na które bezpośrednio lub pośrednio jednostka miała wpływ. Zatem, uczucie dumy oparte jest pośrednio na sukcesach innych (jak np. rodzic dumny z osiągnięć swoich dzieci). Ten wymiar najwyraźniej zaznaczył się $w$ wypowiedziach nauczycieli. Badani uznawali sukcesy swoich uczniów za swoje i czuli z tego powodu dumę. Nie zwracali uwagi na inne czynniki mogące przyczynić się do sukcesu ucznia. Uznawali, że ich własna praca, właśnie ich wkład w nauczanie był na tyle duży, że uczeń osiągnął dobre rezultaty w konkursach i olimpiadach.

Oczywiście, postronny obserwator z łatwością zauważy wiele innych czynników mogących wpływać na wyniki ucznia. Zaliczyć do nich możemy samodzielną pracę ucznia, samodzielne zdobywanie i poszerzanie wiedzy $\mathrm{w}$ danym zakresie, pracę rodziców $\mathrm{z}$ uczniem, uczestniczenie $\mathrm{w}$ zajęciach dodatkowych jak koła zainteresowań, czy korepetycje. Jednakże, nauczyciele osiągnięcia uczniów łączyli bezpośrednio z własną pracą. Może wynikać to $\mathrm{z}$ faktu, że praca nauczyciela jest mało wymierna. Oceniając wkład pracy, przygotowanie do lekcji, trudno jednak ocenić, który nauczyciel uczy lepiej.

${ }^{33}$ L. Festinger, A theory of social comparison processes, Human Relations, 1954, 7, s. 117-140. 
Dlatego, jednym z elementów oceny pracy nauczyciela jest wskaźnik przyrostu wiedzy uczniów.

Dzieci rozpoczynające naukę na danym poziomie edukacji (szkoła podstawowa, gimnazjum, liceum itp.) są poddawane serii testów mających ocenić ich poziom wiedzy na wejściu. Następnie taki sam sprawdzian kompetencyjny (egzamin) piszą na wyjściu ze szkoły. Porównuje się wyniki i otrzymuje wskaźnik przyrostu wiedzy $\left(E^{2} D^{34}\right)$. Czym jest on wyższy, tym uznaje się, że dana szkoła, dany nauczyciel lepiej uczy. I ponownie zapomina się tutaj o kilku istotnych zmiennych mogących wpływać i zaburzać wysokość wskaźnika. Niektóre z nich wymienione zostały powyżej (zainteresowania ucznia, praca rodziców, korepetycje), ale dochodzą tu takie zmienne, jak środowisko wychowawcze, moda na uczenie się lub na nieuczenie się ${ }^{35}$, posiadana na wejściu wyższa niż przeciętna wiedza uczniów. W tym ostatnim przypadku przyrost wiedzy może być de facto mniejszy, pomimo wysokiego poziomu nauczania i dużego wkładu nauczyciela w proces edukacji. Istotny jest fakt, że nauczyciele podzielają pogląd o bezzasadności stosowania tego typu wskaźników.

Praca nauczyciela łączy się z przė̇ywaniem przeróżnych emocji - od radości wynikającej z tego, że na przykład eeee można kogoś nauczyć eeee do frustracji, kiedy się okazuje, że wysitek włożony w edukacje jakiejś klasy czy konkretnej osoby właściwie nie przynosi efektów. Te prace przede wszystkim charakteryzuje to, że musimy cieszyć się z matych sukcesów własnych uczniów, takich, które dla nich są ogromne, ale powiedzmy jeśli chodzi o brutalne szkolne statystyki i na przykład (eee) EWD tak, czyli ten taki system oceny jakości pracy szkoty no one będa powiedzmy niskie tak, natomiast nauczyciel indywidualnie cieszy się z tego, że jego uczeń zamiast $30 \%$ na maturze dostaje 55. W skali Polski czy Łodzi nie jest to jakiś rewelacyjny wynik, ale dla konkretnego dziecka jest on bardzo wysoki tak. Także emocje sa rzeczywiście zwiqzane z praca takie skrajne bym powiedziała - od radości do frustracji (kobieta, lat 44, nauczyciel języka polskiego, szkoła średnia).

Naturalne jest, że rodzic cieszy się z pozytywnych osiągnięć swojego dziecka. Każdy z nas ma tendencję do przypisywania sobie zasług, nawet takich, na które miał niewielki wpływ. Zachowanie takie podtrzymuje samoocenę oraz wpływa na jakość interakcji społecznych. Sukces innych,

${ }^{34}$ Metoda EWD to zestaw technik statystycznych pozwalających zmierzyć wkład szkoły $\mathrm{w}$ wyniki nauczania. Więcej na temat EWD czytelnik znajdzie np. w rozdziale czwartym Raportu o stanie edukacji 2014 - Egzaminy zewnętrzne w polityce i praktyce edukacyjnej, red. R. Dolata, M. Sitek, Warszawa 2015.

${ }^{35}$ Moda na nieuczenie się najczęściej obserwowana była w gimnazjach. Nauczyciele w wywiadach podkreślali, że najtrudniej uczy się w klasie drugiej gimnazjum ze względu na fakt braku zainteresowania nauką ze strony uczniów. 
w którym mieliśmy choć częściowy udział, cieszy, buduje dodatni afekt. Jest to pozytywne zjawisko w kontekście interakcyjnym. Pozwala nam odczuwać pozytywne emocje w większej liczbie sytuacji. Powoduje, że stajemy się osobami zadowolonymi. Rośnie nasza samoocena, co znowu przekłada się na jakość relacji społecznych. Badani nauczyciele mówili o odczuwanej dumie z powodu zainteresowania uczniów przedmiotem oraz drobnych i spektakularnych sukcesach uczniów.

Sukcesem byty czołowe miejsca uczniów w konkursach języka rosyjskiego. Dumna jestem z tego, że kilka moich uczennic ukończyło filologię rosyjską. Jedna uczennica studiowała nawet w Rosji, w St. Petersburgu. To mite (kobieta, lat 67, emerytowany nauczyciel).

Trudno obiektywnie stwierdzić, czy wybór kierunku studiów przez uczennice podyktowany był rzeczywistym zainteresowaniem przedmiotem, rozbudzonym przez nauczycielkę, czy wyborem zasugerowanym przez rodziców, znajomych, czy też kwestią przypadku. Jednak uzasadnienie sukcesu przyjęte przez nauczycielkę wskazuje na chęć utrzymania schematu Ja i wiąże się ze wzrostem statusu, co przekłada się na odczuwanie dumy.

Nigdy nie musiałam podnieść głosu, a na moich lekcjach panowało skupienie i cisza. O tym jak umiałam, choć brzmi to nieskromnie (słyszalna duma w głosie), zainteresować uczniów swoim przedmiotem świadczy to, że kilkunastu z nich ukończyło studia polonistyczne (kobieta, lat 84, emerytowany nauczyciel).

Poza chęcią utrzymania schematu Ja, mamy tu do czynienia z atrybucją wewnętrzną oraz refleksją nad przyczynami. Nauczycielka łączy ciszę występującą na lekcji z umiejętnością zainteresowania uczniów przedmiotem oraz z wysoką oceną własnej pracy zawodowej. Ponownie, trudno zweryfikować interpretację zachowań uczniów przytoczoną przez emerytowaną nauczycielkę. Jednakże możliwą interpretacją takiego zachowania młodzieży jest pojawienie się u uczniów emocji strachu wynikającego z wysokiego poziomu władzy nauczycielki.

To jest wdzięczna praca. Widać osiągnięcie swoich celów. Można zaobserwować przełożenie swojej pracy na osiagnięcia ucznia. Mogę cieszyć się sukcesem dziecka jak swoim. Jestem duma ze swoich uczniów (kobieta, lat 37, nauczyciel).

Najczęściej duma jest reakcją pojawiającą się wówczas, kiedy pracownikowi uda się zrobić lub osiągnąć coś zamierzonego. Rozmówcy wskazywa- 
li na to uczucie dumy, uśmiech oraz radość. Opowiadali o podejmowaniu $\mathrm{w}$ takiej sytuacji zachowania mającego na celu chwalenie się swoim sukcesem i swoimi osiągnięciami. Duma pojawia się jako reakcja na awans oraz jako efekt kontaktu ze współpracownikami. W innych sytuacjach rozmówcy wskazywali na satysfakcję i/lub zadowolenie jako emocje towarzyszące ich zachowaniom w pracy. Przy czym, należy zauważyć, że satysfakcja i zadowolenie to emocje towarzyszące emocji dumy.

W większości koncepcji dotyczących emocji dumy nacisk kładzie się na czynniki prowadzące do powstania tego uczucia. Badacze zastanawiają się jakie emocje, jakie sytuacje i jakie warunki mogą wywołać uczucie dumy. Kładą nacisk na interakcje jako element wywołujący pojawienie się jej. W niniejszych rozważaniach proponuję poczynić krok dalej i zastanowić się, jak uczucie dumy wpływa na zachowanie, percepcję siebie oraz postawę jednostki. Okazuje się, że uczucie dumy może być kołem napędowym powstania kolejnych pozytywnych emocji oraz może prowadzić do podwyższenia samooceny jednostki. Najczęściej duma implikuje pojawienie się emocji radości i odwrotnie: radość może poprzedzać pojawienie się dumy. Czynnikami wywołującymi dumę są kolejno:

- podtrzymywanie przez ucznia kontaktu z nauczycielem po skończeniu edukacji w danej szkole;

- wybór przez ucznia kierunku studiów zgodnego z nauczanym przez nauczyciela przedmiotem;

- możliwość „chwalenia się” uczniem, osiągnięcia uczniów;

Cieszymy się z każdego najmniejszego sukcesu. Ja w swojej pracy zawodowej mam wielu uczniów, którzy poszli na kierunki studiów, moich studiów. Tak, że no myślę, że jest to kilka takich osób, sa osoby, które zajmują się teatrem, zajmują się filmem, zajmują się dziennikarstwem. Myślę, że jest to pewnego rodzaju sukces również dla mnie, bo przychodza i opowiadają o tym. Jest to naprawdę bardzo mite dla nauczyciela i myślę, że nawet jak znajdzie się raz na jakiś czas uczeń, który, którym można się pochwalić, który ma mite wspomnienia ze szkoła, z danym przedmiotem to jest to taka perełka, która daje nauczycielowi takich skrzydeł, uskrzydla i jest satysfakcja pewnego rodzaju, tak. Nie dyplom, nie nagroda dyrektora, nie prezydenta, ale wtaśnie takie efekty, które ptyna od dzieci. Absolwenci, którzy nas licznie odwiedzaja w szkołach sa też pewnego rodzaju no takim, takim uskrzydleniem, że warto pracować, że warto się poświęcać dzieciom, warto się angażować w ich sprawy czasami rodzinne (kobieta, lat 45 lat, obecny nauczyciel);

- wdzięczność płynąca od uczniów; 
- oznaki sympatii okazywane przez uczniów (głównie dotyczy to nauczycieli klas młodszych);

Wdzięczność dzieci ich radość i to, że wiem że lubia mnie, że lgna do mnie i satysfakcja jeżeli jednak uda się ich czegoś nauczyć. Tak to bardzo wdzięczna jest taka praca (...) jak mówię najbardziej te efekty widać pod koniec roku, kiedy faktycznie te dzieci się przytulaja, nie chca odchodzić. Cieszę się, że wybratam ten zawód (kobieta, lat 43 , obecny nauczyciel);

- wywoływanie pozytywnych emocji u uczniów i ich rodziców;

- pozytywne nastawienie do pracy.

Widzę po prostu że sa uśmiechnięte dzieciaki, zadowoleni rodzice, to ja też jestem zadowolona z efektów swojej pracy. Myślę, że to jest właśnie zaleta tej pracy. Ta radość moja, dzieciaków i rodziców. Chce mi się wtedy pracować (kobieta, lat 44, obecny nauczyciel).

Nauczyciele starają się doceniać osiągnięcia swoich uczniów i jest to dla nich wymierny wskaźnik ich efektywności. Obecni oraz byli uczniowie nieświadomie przyczyniają się do wzrostu zadowolenia i satysfakcji z pracy nauczyciela. Są miernikiem sukcesu nauczyciela. Może to dodatnio wpływać na powstanie i trwanie interakcji społecznych. Należy jednak zaznaczyć, że duma jednej osoby może powodować zazdrość innej, co będzie z kolei negatywnie wpływać na rodzaj i formę interakcji.

Takim najbardziej pozytywem jest to, że przychodza absolwenci, którzy czasem skończyli bardzo dawno szkołę. Przychodza, wyczekuja tego dnia otwartego, kiedy można przyjść, przychodza zawsze bardzo licznie i jest to myśle w takim środowisku nauczycielskim taki bardzo duży pozytyw, gdzie koleżanki $i$ koledzy patrza krzywym okiem czasami właśnie, że do danej osoby przychodzi tak dużo osób, a do innych mniej. Może to też jest takie śmieszne, ale no niestety tak jest w środowisku nauczycielskim, też jest zazdrość, że ktoś jest bardziej lubiany, a ktoś mniej lubia$n y, k$ toś bardziej wspominany, mniej wspominany (kobieta, lat 45 lat, obecny nauczyciel).

W kontekście niniejszych badań można wskazać, że uczucie dumy wpływa na wzrost motywacji do działania i pracy. Zatem, pracodawcy powinni starać się kreować sytuacje, w których pracownicy będą mogli uczestniczyć w sytuacjach umożliwiających pojawienie się uczucia dumy. Model przyczyn i konsekwencji pojawiania się emocji dumy prezentuje rycina 1. 


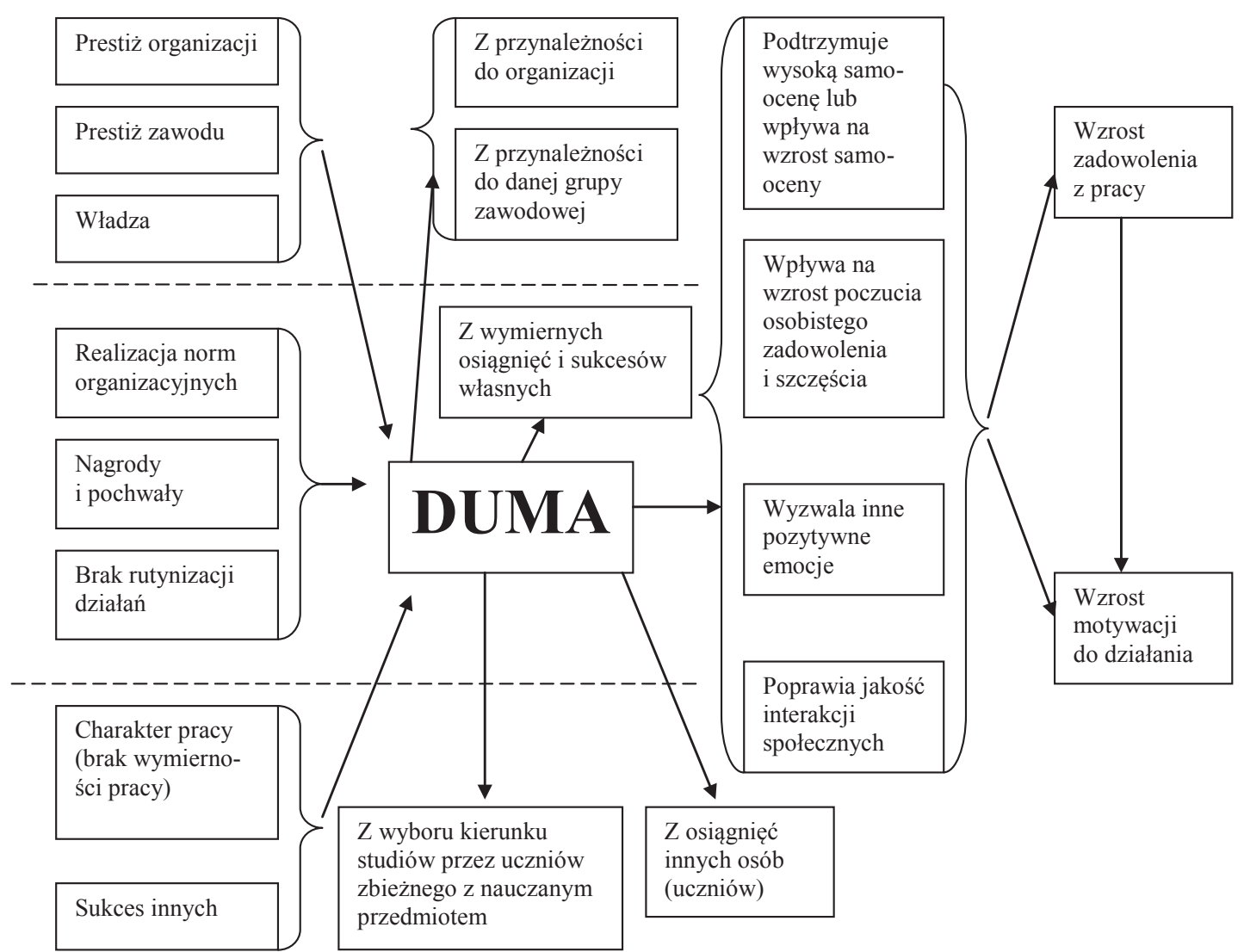

Ryc. 1. Model przyczyn i konsekwencji pojawiania się emocji dumy

(źródło: opracowanie własne)

\section{Szkoła w retrospektywnej perspektywie uczniów}

Jak zostało wspomniane na początku artykułu, szkoła to przede wszystkim jej uczniowie. Bez nich nie byłoby szkoły. Dlatego, moim zdaniem, warto zobaczyć jakie emocje przeżywane w szkolnych murach zostają zapamiętane. Tym samym, można przyjąć założenie, że wpływają one na późniejszą tożsamość jednostki i podejmowane przez nią działania.

W tym celu poprosiłam studentów (31 osób) drugiego roku analityki społecznej, studiujących w trybie dziennym, o przeprowadzenie wywiadów swobodnych dotyczących ich edukacji. Studenci przeprowadzali wywiady wzajemnie między sobą, oparte na krótkich dyspozycjach dotyczących kolej- 
nych etapów edukacji z uwzględnieniem (wskazaniem) emocji pojawiających się $\mathrm{w}$ toku ich edukacji. Następnie wywiady zostały spisane i zakodowane zgodnie z paradygmatem kodowania otwartego, a następnie zogniskowanego. Autorka zdaje sobie sprawę z jednorodnego doboru respondentów, których stanowią studenci zaledwie jednego kierunku. Uwzględniając jednak fakt zastosowania techniki jakościowej, proponuję krótkie prześledzenie wstępnych wyników tego badania.

Wszystkie wywiady zostały wyraźnie podzielone na etapy szkolne (szkoła podstawowa, gimnazjum, szkoła średnia, kilkakrotnie pojawiło się także przedszkole). Świadczyć może to o zróżnicowanym charakterze emocji pojawiających się na różnych szczeblach edukacji, jak również o zmianie statusu podczas przejścia i stanowieniu punktu zwrotnego w trajektorii jednostki. We wszystkich opisach można odnaleźć informacje o istotności zmiany szkoły oraz towarzyszących tym zmianom emocjom: lęku, strachu, niepokoju.

Oczywiście, gdy już nadszedł ten pierwszy dzień, w którym byłem tė̇ pełny obaw i strachu przed tym, co nieznane i przed tym jak będą odbierać moją osobę inni (mężczyzna, lat 23 - etap szkoły podstawowej).

Analizując emocje towarzyszące poszczególnym etapom edukacji, można powiedzieć, że najwięcej emocji pozytywnych towarzyszy edukacji na etapie przedszkolnym i wczesnoszkolnym. Edukacja w klasach 1-3 z reguły budzi radość, ciekawość, zaangażowanie.

Chodzenie do szkoty podstawowej bardzo mi sie podobało, te wszystkie prace domowe, dodatkowe zajęcia, kiedy wracałam do domu pierwsza rzecza jaka się zajmowałam po było odrabianie pracy domowej (kobieta, lat 21 - etap szkoły podstawowej).

Najistotniejsza z punktu widzenia problematyki artykułu jest emocja dumy i związane z nią poczucie satysfakcji. Jest ona wynikiem działania odczytywanego przez ucznia jako osiągnięcie sukcesu. Wymiar sukcesu określany jest indywidualnie przez ucznia, choć jest wzmacniany, kiedy działanie ma charakter publiczny (np. pochwała przy całej klasie, odbiór nagrody na oczach uczniów całej szkoły itp.).

Pojawiło się uczucie samozadowolenia, a może nawet dumy, kiedy zostałem pochwalony przez swoja przedszkolanke, że umiem czytać najlepiej z całej grupy (...). W piątej klasie podstawówki - występ w gminnych zawodach - pierwsze miejsce w biegu na $60 \mathrm{~m}$ i skoku w dal. Myślę, że wtedy poczułem coś na ksztatt nawet i dumy. Osiagnięcie może i dla niektórych niewielkie, dla mnie jednak wymierna na- 
groda za aktywność na zajęciach WF-u. Szósta klasa, kolejny występ, tym razem na zakończenie roku i moje pożegnanie ze szkoła podstawowa. Główna rola w jednym $z$ dwóch przedstawien, nie czułem zupetnie stresu, wyluzowany odegrałem swoja role, po reakcji publiczności wywnioskowatem że nic nie spartoliłem. Było to kolejne uczucie zadowolenia, a przynajmniej kolejne, które pamiętam (mężczyzna, lat 21 etap przedszkolny oraz szkoły podstawowej).

Emocja dumy wzmacniana jest również przez zachowanie znaczących innych. Ważną rolę w procesie odczuwania emocji dumy odgrywają rodzice, którzy mogą pojawiającą się emocję wzmocnić lub wygasić w procesie interakcji.

Mój tato zawsze powtarza do mnie i siostry, że my jesteśmy inteligentne, co powoduje zawsze dumę. (...) Pod koniec klasy III pisaliśmy tak zwane próbne trzecioteściki, z których dostałam same piatki, testy z ubiegtych lat byto ich okoto 5. Byłam bardzo szczęśliwa, mało osób dostało ze wszystkich piątki, zostałam pochwalona na wywiadówce, rodzice byli bardzo dumni i ja czułam, że w końcu pokazałam na co mnie stać $i \dot{z}$ e dostanę nagrodę $i$ wyjdę po nia na zakończeniu roku szkolnego (kobieta, lat 21 - etap szkoły podstawowej).

Emocja dumy pojawia się również $\mathrm{w}$ wyniku rozwiązanego z korzyścią dla ucznia konfliktu z nauczycielem. Studenci pisali o „wygranej z nauczycielem" i odczuwanej satysfakcji.

Warto zaznaczyć, że emocja dumy może mieć charakter zbiorowy i w opisie retrospektywnym niejednokrotnie studenci wskazywali na klasę szkolną jako podmiot zbiorowy jednocześnie odczuwający przeżywaną przez jednostkę emocję dumy.

Dzięki temu czuliśmy jako klasa dumę i wyższość nad innymi piąymi klasami, nie wspominajac już o klasach niższych (mężczyzna, lat 20 - etap szkoły podstawowej).

W pisemnych wypowiedziach studentów analityki społecznej w narracjach zaznacza się negatywne zabarwienie emocjonalne. We wspomnieniach edukacji najwięcej mówiono o konfliktach z nauczycielami (rozwiązanych pozytywnie, gdzie nauczyciel potrafił rozwiązać sytuację konfliktową zyskując szacunek i autorytet lub rozwiązanych negatywnie, gdzie nauczyciel stawał się przedmiotem kpin i żartów, wywoływał zachowania agresywne, w tym odwetowe, lub budził lęk i niepokój potęgując brak szacunku, złość i eskalację konfliktu) oraz poczuciu niesprawiedliwości. Opis dumy, radości i satysfakcji pojawia się rzadko i najczęściej związany jest z interakcją z rówieśnikami, a nie wynika z pozytywnych działań nauczyciela. 


\section{Podsumowanie}

W rezultacie przeprowadzonych badań można stwierdzić, że występują istotne rozbieżności w postrzeganiu szkoły pomiędzy nauczycielami a uczniami. Nauczyciele w wywiadach podkreślali głównie pozytywne aspekty pracy w szkole. Przedstawiali siebie jako osoby chcące nie tylko przekazać wiedzę, ale także pomóc uczniom w rozwiązaniu różnych problemów, w tym problemów rodzinnych. Niestety, uczniowie $\mathrm{w}$ większości nie podzielają tego poglądu. Nauczycieli postrzegają często jako symbol represji i opresji, jako jednostki wywołujące stres, strach, przerażenie, obawę i nie zwracające uwagi na problemy uczniów. Z pewnością, interesujące będzie pogłębienie tych badań i uzyskanie danych od większej liczby byłych uczniów.

Odnosząc się do emocji dumy, jako tej stanowiącej o podtrzymywaniu więzi społecznej oraz zwiększającej samoocenę jednostki, można stwierdzić, że odczuwanie dumy bez wątpienia wpływa na wzrost satysfakcji z pracy, powodując intensyfikację wysiłku pracownika oraz wzrost działań podejmowanych w celu realizacji zamierzeń.

\section{BIBLIOGRAFIA}

Burawoy M., The Extended Case Method, Sociological Theory, 1998, 16(1).

Charmaz K., Constructing Grounded Theory: A Practical Guide Through Qualitative Analysis, Sage, London - Thousand Oaks - New Delhi 2006.

Charmaz K., Teoria ugruntowana. Praktyczny przewodnik po analizie jakościowej, Wydawnictwo Naukowe PWN, Warszawa 2009.

Deegan M.J., The Chicago School of Ethnography, [w:] Handbook of Ethnography, red. P. Atkinson, A. Coffey, S. Delamont, J. Lofland, L. Lofland, Sage, Thousand Oaks 2001.

Doktór K., Przedsiębiorstwo przemystowe. Studium socjologiczne Zakładów Przemystu Metalowego „Cegielski”, Książka i Wiedza, Warszawa 1964.

Dolata R., Sitek M., Egzaminy zewnętrzne w polityce i praktyce edukacyjnej. Raport o stanie edukacji 2014, Instytut Badań Edukacyjnych, Warszawa 2015.

Festinger L., A theory of social comparison processes, Human Relations, 1954, 7.

Glaser B.G., Strauss A.L., The Discovery of Grounded Theory: Strategies for Qualitative Research, Aldine, Chicago 1967.

Glaser B.G., Strauss A.L., Odkrywanie teorii ugruntowanej. Strategie badania jakościowego, Zakład Wydawniczy Nomos, Kraków 2009.

Goffman E., Instytucje totalne. O pacjentach szpitali psychiatrycznych i mieszkańcach innych instytucji totalnych, Gdańskie Wydawnictwo Psychologiczne, Sopot 2011.

Goleman D., Inteligencja emocjonalna, Media Rodzina, Poznań 1997.

Gorzko M., Procedury i emergencja. O metodologii klasycznych odmian teorii ugruntowanej, Wydawnictwo Uniwersytetu Szczecińskiego, Szczecin 2008.

Hammersley M., Atkinson P., Ethnography: Principles in Practice, Taylor and Francis Group, New York 2007.

Hofstede G., Kultury i organizacje, Polskie Wydawnictwo Ekonomiczne, Warszawa 2000. 
Kemper T., A Social Interactional Theory of Emotions, Wiley, New York 1978.

Kemper T., How many emotions are there? Wedding the social and autonomic components, American Journal of Sociology, 1987, 93, s. 263-289.

Kemper T., Predicting Emotions from Social Relations, Social Psychology Quarterly, 1991, 54.

Kemper T., Modele społeczne w wyjaśnianiu emocji, [w:] Psychologia emocji, red. M. Lewis, J.M. Haviland-Jones, Gdańskie Wydawnictwo Psychologiczne, Gdańsk 2005.

Kemper T., Power, status, and emotions, [w:] Emotions a social science reader, red. M. Greco, P. Stenner, Routledge Taylor and Francis Group, London - New York 2008.

Konecki K., W japońskiej fabryce, Wydawnictwo Uniwersytetu Łódzkiego, Łódź 1992.

Konecki K., Studia z metodologii badań jakościowych. Teoria ugruntowana, Wydawnictwo Naukowe PWN, Warszawa 2000.

Konecki K., Pawłowska B. (red.), Emocje w życiu codziennym. Analiza kulturowych, społecznych $i$ organizacyjnych uwarunkowań ujawniania $i$ kierowania emocjami, Wydawnictwo Uniwersytetu Łódzkiego, Łódź 2014.

Lutyński J., Metody badań społecznych. Wybrane zagadnienia, Łódzkie Towarzystwo Naukowe, Łódź 1994.

Pawłowska B., Emocje społeczne w pracy nauczyciela i przedstawiciela handlowego, Wydawnictwo Uniwersytetu Łódzkiego, Łódź 2013.

Pawłowska B., Emocje społeczne w teorii Theodore'a Kempera, [w:] Emocje w życiu codziennym. Analiza kulturowych, społecznych i organizacyjnych uwarunkowań ujawniania i kierowania emocjami, red. K. Konecki, B. Pawłowska, Wydawnictwo Uniwersytetu Łódzkiego, Łódź 2014.

Przybyłowska I., Wywiad swobodny ze standaryzowana lista poszukiwanych informacji i możliwości jego zastosowania w badaniach socjologicznych, Przegląd Socjologiczny, 1978, XXX.

Raport o stanie edukacji 2014 - Egzaminy zewnętrzne w polityce i praktyce edukacyjnej, red. R. Dolata, M. Sitek, IBE, Warszawa 2015.

Robert Ch., Probst T., Martocchio J., Drasgow F., Lawler J., Empowerment and Continuous Improvement in the United States, Mexico, Poland, and India: Predicting Fit on the Basis of the Dimensions of Power Distance and Individualism, Journal of Applied Psychology, $2000,85,5$.

Scheff T., Shame and Conformity: The Deference Emotion System, American Sociological Review, 1988, 53.

Scheff T., Microsociology. Discurse, emotion, and social structure, University of Chicago Press, Chicago 1990.

Scheff T., Shame and the social bond, and human reality, Cambridge University Press, New York 2000.

Scheff T., Shame and self in society, Symbolic Interaction, 2003, 26.

Stets J., Identity Theory and Emotions, [w:] Handbook of the Sociology of Emotions, red. J.E. Stets, J.H. Turner, Springer, New York 2006.

Strauss A.L., Corbin J., Grounded Theory in Practice, Sage, Thousand Oaks 1997.

Strongman K., The psychology of emotions. Fifth edition. From everyday life to theory, Wiley, Chichester 2003.

Turner J., Stets J., Socjologia emocji, Wydawnictwo Naukowe PWN, Warszawa 2009. 